\title{
ANALISIS GEMPA SUMBA BARAT 2016 ATAS MINIMNYA DAMPAK YANG DITIMBULKAN
}

\section{ANALYSIS OF THE 2016 SUMBA BARAT EARTHQUAKE RELATED TO IT'S MINIMUM IMPACT}

\author{
Wisyanto \\ Pusat Teknologi Reduksi Risiko Bencana, BPPT, JI. MH. Thamrin 8, Jakarta \\ e-mail:wisyanto@bppt.go.id
}

\begin{abstract}
The 2016 Februari Sumba Earthquake whose epicenter was on land and with magnitude of 6.6 $\mathrm{Mb}$ did not bring a serious impact in West Sumba. It has attracted the attention of many people, particularly the researchers, so that it has been done a fieldwork on these events. Besides of secondary data, assessment method has also been based on a field observation along the path of Waykabubak City to the south coast around Wanokaka Region, where the epicenter was. The field study includes observation of the geological aspects, the shaking impact on building and quality testing of building material. The results showed that the high stability of the continental crust that became the bedrock of Sumba Island, thin soil so that the foundations of a building directly rested on a rock and there are many stilt houses / custom homes have minimized the impact of the earthquake waves.
\end{abstract}

Keywords: Earthquake impact, Continental Crust, Building, Stilt House

\begin{abstract}
ABSTRAK
Gempa Sumba Februari 2016 yang berepisenter di darat dan dengan magnitudo 6,6 Mb ternyata tidak membawa dampak serius di Sumba Barat. Hal ini telah menarik perhatian, sehingga dilakukan kajian lapangan terhadap peristiwa ini. Metode kajian yang dilakukan, selain dengan pemahaman data sekunder, juga dilakukan kajian lapangan di sepanjang lintasan Kota Waykabubak sampai ke pesisir selatan di sekitar Daerah Wanokaka, di mana episenter berada. Kajian lapangan meliputi pengamatan aspek geologi, dampak gempa terhadap bangunan dan pengukuran kuat struktur gedung. Hasil kajian menunjukkan bahwa tingginya kestabilan kerak kontinen yang menjadi batuan dasar Pulau Sumba, tipisnya soil sehingga fondasi bangunan langsung menumpu pada batuan dan masih banyaknya rumah panggung/ rumah adat telah meminimalisir dampak gelombang gempa yang terjadi.
\end{abstract}

Kata kunci: Dampak gempa, Kerak Kontinen, Bangunan, Rumah Panggung

\section{PENDAHULUAN}

Indonesia Bagian Timur sedikit berbeda dengan Wilayah Indonesia bagian barat dalam masalah kegempaannya. Secara tektonik, Wilayah Indonesia Bagian Timur ini lebih rumit dibandingkan dengan Wilayah Indonesia Bagian Barat. Dengan kondisi yang lebih rumit ini, maka variasi kegempaan juga lebih beragam. Ada satu bagian yang mudah melepaskan energinya sehingga sering terjadi gempa dengan skala relatif kecil, ada bagian lain yang membentuk kondisi penguncian sehingga jarang terjadi gempa, namun hal ini berpotensi menimbulkan ancaman gempa yang tinggi (Yanchuan et al., 2016) dan ada wilayah yang sering mengalami gempa (hampir) secara bersamaan (swarm earthquake) karena satu gempa mempengaruhi sistem tegasan batuan yang ada di sampingnya (Spicak and Vanek, 2016) seperti yang sering terjadi di Papua bagian tengah atau mungkin karena adanya gangguan sistem tegasan lokal oleh tegasan regional (Babuska et al., 2016).

Gempabumi merupakan ancaman yang sangat nyata bagi masyarakat Indonesia, khususnya mereka yang hidup di sekitar zona aktif pertemuan lempeng. Tingkat kerentanan suatu daerah terhadap bencana gempabumi, dipengaruhi oleh 
banyak hal, di antaranya adalah kondisi geologi (batuan, soil, dan struktur geologi), kegempaan, kondisi bangunan dan kesiapan masyarakatnya. Pengamatan dan penyelidikan lapangan akan suatu peristiwa gempabumi sangat bermanfaat, selain untuk perbaikan kondisi dalam menghadapi bencana kedepan bagi daerah bersangkutan, juga untuk memetik pelajaaran berharganya bagi daerah lainnya. Banyak contoh dampak gempa yang sangat berbeda atas suatu peristiwa yang relatif sama besar goncangannya (shaking map). Hal ini biasanya terkait erat dengan adanya perbedaan kualitas bangunan dan kesiapsiagaan masyarakatnya.

Terkait dengan peristiwa gempa Sumba yang terjadi pada 12 Februari 2016, penulis sangat tertarik dengan kabar elektronik yang menyebutkan bahwa adanya gempa tersebut, pihak luar di antaranya BNPB tidak bisa menghubungi pemda setempat karena jaringan telepon dan internet mati. Hal ini menunjukkan tanda-tanda seriusnya dampak gempa yang terjadi. Mengingat daerah Sumba mempunyai tatanan tektonik yang khusus, relatif berbeda dengan bagian barat dan timurnya, maka penulis melakukan kajian gempa di Sumba tersebut. Diharapkan bahwa dengan kajian yang dilakukan, akan dapat diketahui seberapa dampak gempa yang terjadi dan mekanisme kejadiannya.

\section{METODE PENELITIAN}

\subsection{Lokasi Penelitian}

Daerah penelitian terletak di sepanjang Kota Waykabubak sampai kearah pesisir selatan di Daerah Wanokaka, tempat episenter gempa. Adapun waktu penelitian dilakukan selama 6 hari, mulai 14 Februari sampai 19 Februari 2016.

\subsection{Metode Penelitian}

Penelitian ini dilakukan melalui beberapa tahapan, yaitu:

- Pengumpulan data geologi dan kegempaan.

- Mempelajari sejarah kegempaan dan tektonik wilayah Sumba.

- Mengumpulkan data sekunder tentang peristiwa dan dampak gempa.

- Melakukan penelitian lapangan berupa pengamatan geologi sepanjang lintasan Kota Waykabubak sampai ke pesisir selatan di sekitar Daerah Wanokaka, di mana episenter berada.

- Melakukan pengamatan dampak gempa di sepanjang lintasan penelitian, serta mengukur kekuatan bangunan dari beberapa sampel gedung yang rusak dan yang tidak rusak.

- Melakukan analisis data yang didapat dikaitkan dengan mekanisme gempa dan fenomena tektonik daerah Sumba Barat.

\section{HASIL DAN PEMBAHASAN}

\subsection{Geologi dan Kegempaan Daerah Sumba}

\subsubsection{Geologi Daerah Sumba}

Batuan yang ada di Pulau Sumba berupa batuan sedimen yang tidak termetamorfosis hingga sedikit termetamorfosis berumur Mesozoikum, secara tidak selaras ditumpangi oleh endapan berumur Tersier dan Kuarter yang sedikit sekali terdeformasi. Ketebalan total mencapai lebih dari 1.000 m (van Bemmelen, 1949). Teras-teras terumbu karang yang menutupi tepi bagian yang mengarah ke laut dari Formasi Sumba berumur Neogen, hampir secara kontinu tersingkap ke permukaan di sepanjang pantai barat, pantai utara, dan pantai timur Sumba (Hamilton, 1979).

\section{a. Seri Mesozoikum}

Batuan berumur Mesozoikum tersingkap ke permukaan, terutama di sepanjang pantai seperti bagian selatan dari Sumba Barat (Patiala, Wanokaka dan Konda Maloba) dan pada bagian selatan dari Pegunungan Tanadaro (Sungai Nyengu dan Labung). Tipe sedimen berupa batulanau karbonatan dengan batulempung vulkanogenik, terkadang menunjukkan gejala-gejala metamorfisme tingkat rendah, berlapis dengan batupasir, konglomerat, batugamping dan runtuhan vulkaniklastik. Secara keseluruhan terpotong oleh intrusi berumur Kapur Akhir dengan kisaran komposisi dari mikrogabro hingga diorit-kuarsa, dan juga oleh dykes granodioritic serta kalkalkalin berumur Paleogen. Sedimen menunjukkan struktur slump berskala besar dan perekahan yang kuat. Sedimen tersebut merupakan Formasi Lasipu (Prasetyo, 1981). Material-material detrital salah satunya memberikan kesan asal-muasal dari kontinen, atau lingkungan busur kepulauan; hal tersebut tampak terlihat pada kipas bawah laut berumur Mesozoikum dengan endapan laut dangkal (Von der Borch et al., 1983) atau lingkungan batial laut terbuka (Burollet dan Salle, 1982). 


\section{b. Seri Paleogen}

Selama Paleogen, Sumba merupakan bagian dari busur magmatik yang dikarakterisasi oleh seri batuan vulkanik kalk-alkalin (Sumba Barat) dan sedimen laut dangkal (Abdullah et al.,2000). Endapan yang berhubungan termasuk tuf, ignimbrit, greywackes, sisipan batugamping foraminifera, napal, mikro-konglomerat, dan batulempung. Batuan tersebut secara tidak selaras berada di atas batuan berumur Mesozoikum dan di atasnya secara tidak selaras ditutupi oleh Seri Neogen.

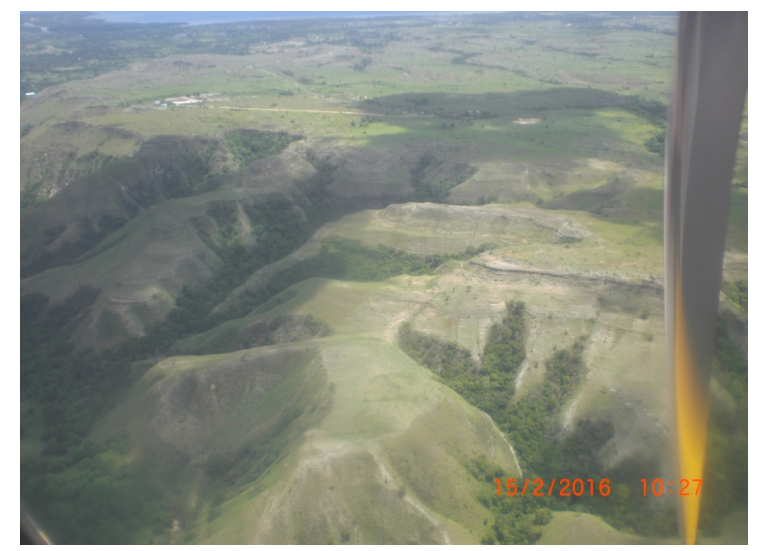

Gambar 1. Kenampakan Topografi Undak/

Teras dari Batupasir, Konglomerat, Napal, dan Batugamping Terumbu yang Terdapat di Daerah Pantai Sumba Barat.

\section{c. Seri Neogen}

Seismik refleksi lepas pantai menunjukkan sedimen laut dalam berumur Neogen membentuk sikuen sedimenter awal dari cekungan muka busur yang menghilang ke arah punggungan (Fortuin et al., 1992; Van der Werff et al., 1994a, b; Van der Werff, 1995; Fortuin et al., 1997). Kejadian ini menunjukkan posisi stabil dari Punggungan Sumba di dalam cekungan muka busur sejak inisiasi sistem palungbusur Sunda selama Oligosen Akhir dan Miosen Awal (Silver et al., 1983; Reed, 1985; Barberi et al., 1987). Sedimen Neogen di Sumba memperlihatkan dua fasies yang berbeda: pada bagian barat, mereka direpresentasikan kebanyakan oleh batugamping terumbu, batugamping bioklastik, batugamping chalky dan napal, berlapis dengan napal tufaan, sedangkan sedimen dari bagian timur Sumba didominasi endapan turbidit vulkanik dengan perlapisan kapur pelagic dan batugamping chalky (Fortuin et al., 1994). Pada bagian pusat Sumba, fasies sedimenter tersebut menunjukkan hubungan menjari. Batuan tersebut umumnya tidak terganggu secara tektonik.

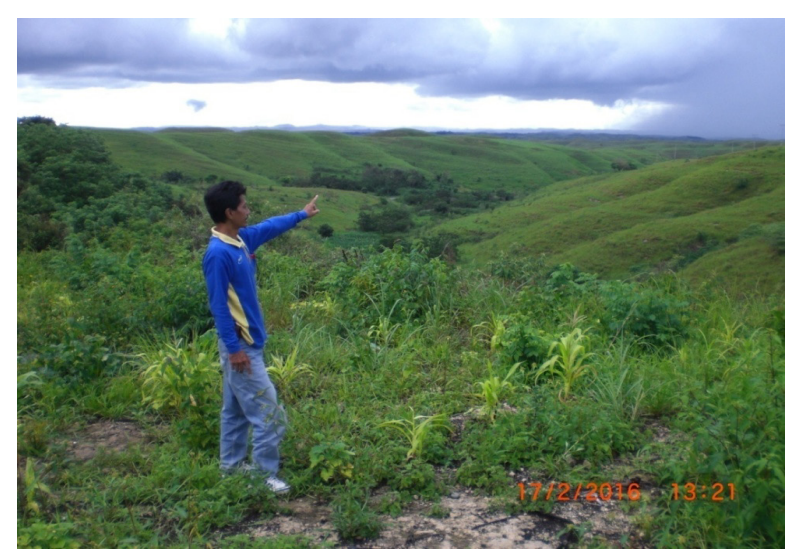

Gambar 2. Kenampakan Morfologi Perbukitan dari Susunan Batuan Tuf dan Sedikit Berselingan dengan Batugamping. Permukaan Hanya Ditumbuhi Rumput Karena Tipisnya Soil.

\section{d. Seri Kuarter}

Keseluruhan pulau telah mengalami pengangkatan dengan cepat terhadap elevasinya sekarang, seperti yang diindikasikan oleh terasteras berumur Kuarter yang mencapai ketinggian tidak kurang dari $500 \mathrm{~m}$ (Jouannic et al., 1988), dengan kecepatan rata-rata $0,5 \mathrm{~mm} /$ tahun pada bagian utara dan tengah Sumba (Pirazzoli et al., 1991). Teras-teras tersebut terdiri dari batupasir, konglomerat, napal dan batugamping terumbu menonjol yang secara tidak selaras dilapisi sedimen berumur Neogen dengan kemiringan relatif tidak curam di sepanjang pantai barat, pantai utara dan pantai timur. Secara lokal, endapan berumur Kuarter diendapkan secara tidak selaras di atas batuan berumur Mesozoikum di sepanjang pantai baratdaya.

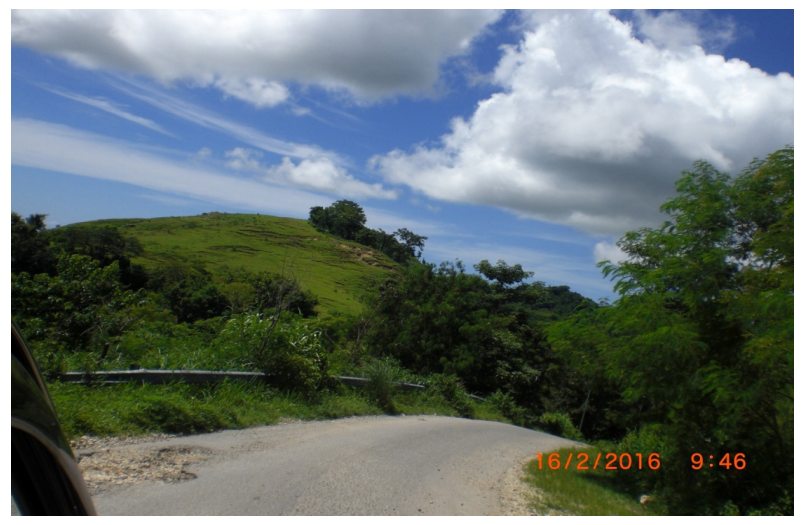

Gambar 3. Topografi Karst Tidak Sempurna dari Perselingan Batugamping dengan Tuf, Daerah Wanokaka 
Kenampakan batuan yang paling umum dijumpai di sepanjang perjalanan dari Waingapu-Waikabubak dan Daerah Wanokaka adalah dominan berupa tuf, batugamping terumbu, batugamping klastik, napal, dan rombakan vulkaniklastik. Batuan tuf ini sering kali dimanfaatkan oleh penduduk menjadi "batu bata" (Gambar 4). Berikut adalah bentang alam yang sangat umum dijumpai di lapangan yang tersusun oleh tuf dengan sisipan batugamping. Sebagian besar berupa perbukitan yang hanya ditutupi rumput ilalang karena tipisnya soil pada permukaan bukitnya. Secara setempat menunjukkan topografi kars (tidak sempurna), khususnya pada tempat-tempat dengan susunan batugamping yang cukup banyak.

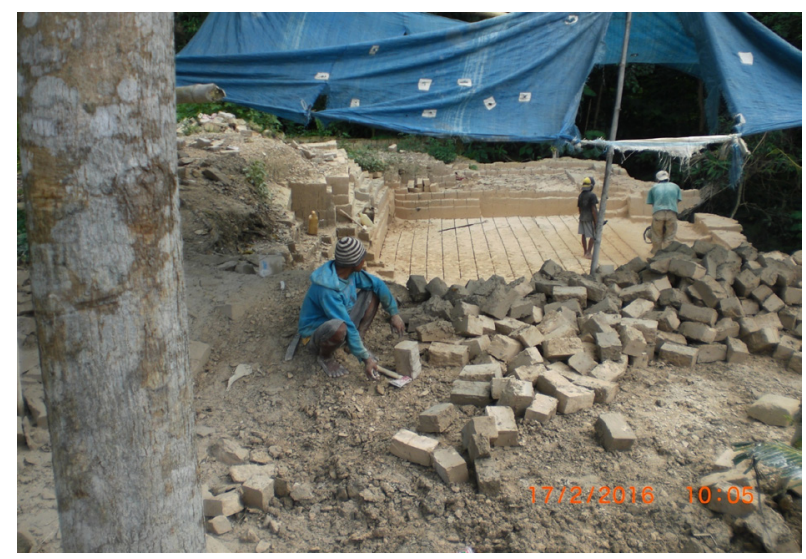

Gambar 4. Batuan Berupa Tuf yang Dimanfaatkan Penduduk sebagai Bahan "Batubata"

\subsubsection{Tatanan Tektonik Sumba}

Secara tektonik, Pulau Sumba merupakan bagian yang berbeda dari pulau-pulau lain di sekitarnya yang berupa busur gunungapi (volcanic arc). Zona penunjaman Indonesia bagian selatan yang menghasilkan busur gunungapi tersebut dimulai dari bagian baratlaut Indonesia, yaitu di Teluk Bengal dan Laut Andaman ke selatan dan berbelok ke timur sejajar dengan panjang Pulau Sumatera dan Jawa sampai ke daerah sekitar Pulau Sumba dan terus ke timur mengikuti Sistem Busur Banda. Zona tektonik aktif ini merupakan interaksi antara Lempeng India-Australia yang menunjam ke bawah Lempeng Eurasia dengan kecepatan 50-70 mm/th. Pulau Sumba memiliki posisi yang khas terkait dengan busur Sunda-Banda yang merepresentasikan sebuah potongan terisolasi dari kerak benua terhadap busur kepulauan vulkanik aktif (Sumbawa, Flores) dalam cekungan muka busur. Pulau Sumba terletak pada transisi antara Palung Jawa (zona penunjaman) dengan Timor Trough (zona tumbukan).
Sumba tidak asli terbentuk pada tempat yang sekarang, tetapi berasal dari tempat lain yang kemudian berjalan selama periode sejarah geologi tertentu, dan akhirnya menempati posisinya sekarang. Data paleomagnetik, umur batuan, karakter batuan, anomali isotop batuan vulkaniknya, dan kandungan fosil-fosilnya menunjukkan bahwa posisi pertama Sumba berada di 18,3 LU yaitu pada sekitar 60 juta tahun yang lalu, dan telah menempati posisinya yang sekarang (9,9 LS) sejak 20 juta tahun yang lalu. Berarti selama 40 juta tahun Sumba berjalan melintasi sekitar 28 derajat garis lintang dari utara ke selatan. Rekonstruksi geologi kemudian menunjukkan bahwa Sumba dulu bersatu dengan sisi timur Sulawesi, di sebelah utara Teluk Bone sekarang (Sulawesi pada masa itu juga posisinya tidak seperti posisinya sekarang). Data paleomagnetik ini juga didukung data fosil, anomali isotop, karakter, dan umur batuan. Sumba memiliki fosil-fosil berumur 40 juta tahun (Eosen) yang khas untuk Sundaland (yaitu fosil Assilina, Pellatispira, dan Biplanispira dan tak memiliki fosil seumur asal Australia/ Lacazinella). Jadi dapat disimpulkan bahwa Sumba pernah menjadi bagian timur Sundaland. Gambaran sederhana dari Pulau Sumba dapat dilihat pada peta-peta berikut (Gambar 5).

Pada sketsa Gambar 5 menunjukkan kondisi Palung Sunda dan Banda pada 5 juta tahun lalu. Timor, Kisar, Moa, Sermata, Babar, Roti, Savu and Sumba masih berada dalam air. Pulau Timor terbentuk setelah tumbukan 3,5 - 2 juta tahun lalu.

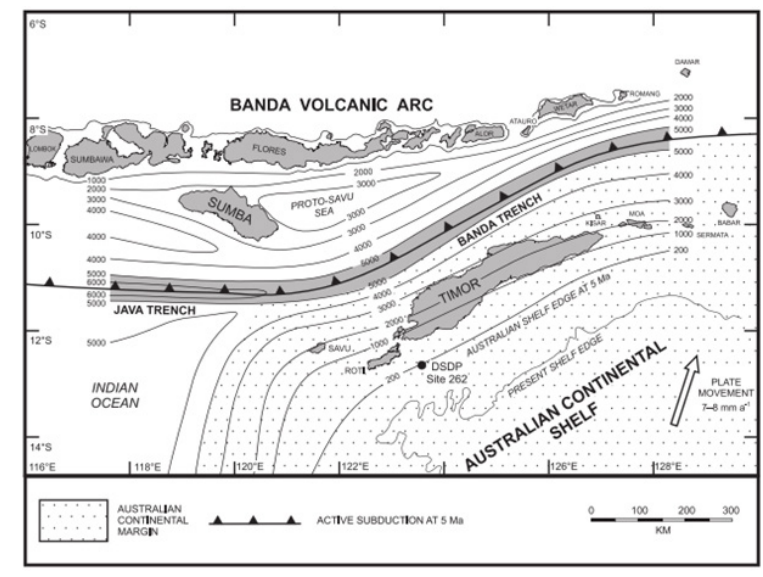

(a) 


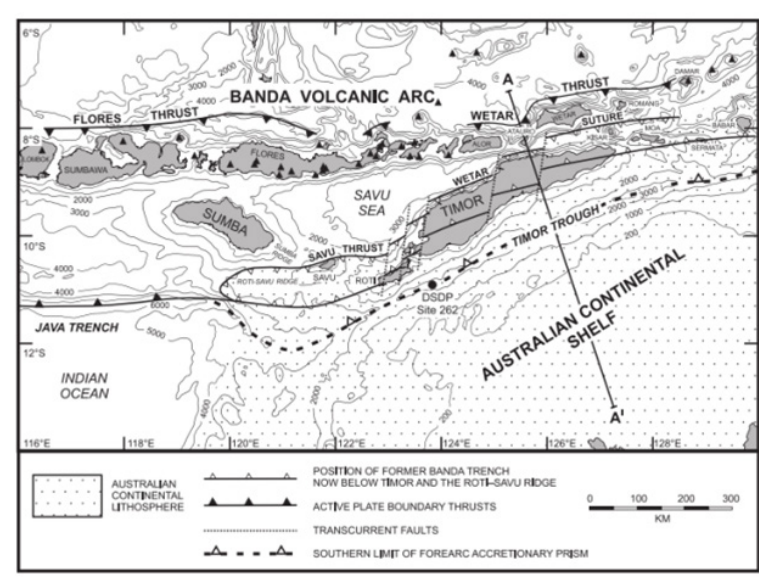

(b)

Gambar 5. a. Kondisi Sumba Sudah pada Tempatnya sejak 5 Juta Tahun Lalu, b. Kondisi Tektonik Sekarang

(Audley-Charles, 2004)

Kondisi Fisiografi dan Tektonik Wilayah Sumba dan Timor berikutnya adalah terlihat pada Gambar 6 . Kondisi sekarang, terdapat penyusupan lempeng ke arah utara pada Palung Jawa, suatu suture lebih muda dan menunjam ke selatan yang menggeser busur volkanik Banda; Savu Thrust yang menunjam ke selatan (Silver et al., 1983) dan Suture Wetar yang terkunci (Audley-Charles, 1981). Tepi Kontinen Australia sekarang terkunci dalam tumbukan dengan Busur Muka Banda dari Wetar sampai Punggungan Sumba. Ujung timur Palung Jawa yang sekarang terkunci oleh Tepian Australia telah ditumpangi oleh busur muka Banda, di mana busur ini sendiri telah ditumpangi oleh endapan insitu sedimen tepi kontinen (para-autochthon) membentuk Punggungan Roti-Savu yang bergerak diatas Sesar Naik Savu.

Bila dilihat dari data geologi dan geofisika, Sumba terbukti dulunya merupakan bagian dari kontinen di utara (Eurasia/ Mikro Sunda), demikian halnya dengan masalah etnogenesis juga mendukungnya. Keunikan Sumba ternyata diikuti oleh karakter linguistik, genetika dan arkeologi megalitik etnik-etnik Sumbanya yang secara umum bercorak Sundaland. Maka sesungguhnya nampak kaitan geologi dengan etnogenesis Sumba.Terdapat koevolusi (coevolution) antara linguistik dan genetika di Sumba. Rekonstruksi filogenetik menunjukkan bahwa bahasa-bahasa Sumba berasal dari satu nenek moyang bahasa Austronesia yang bercorak umum Sundaland (blogspot.co.id). Juga terdapat korelasi positif antara persentase kekerabatan (lineage) kromosom $Y$ (laki-laki) yang juga berasal dari para nenek moyang Austronesia. Dari sebaran kelompok bahasa dan persentasi lineage kromosom $Y$ dapat ditunjukkan bahwa penghunian atau etnogenesis Pulau Sumba terjadi dari sisi utara/ baratlaut Sumba dan kemudian bermigrasi ke timur, barat, dan selatan. Sumba juga terkenal sebagai tempat kebudayaan megalitikum masih terjadi sampai saat modern ini. Perbandingan motif eksterior megalitnya ternyata mirip dengan motifmotif megalit di Sulawesi Selatan, Sulawesi Utara, Jawa Timur, Jawa Barat, dan Nias.

\subsection{Pembahasan}

Berdasarkan histori gempa (catatan USGS) di Pulau Sumba dan sekitarnya, tercatat bahwa gempa yang terjadi pada kurun 2015 sampai 2016 dengan besaran 4-7 SR terdapat 41 kejadian (Gambar 6). Episenter gempa yang terdapat di daratan Sumba, selain gempa besar 12 Februari 2016 kemarin (Gempa Sumba Barat), terdapat 3 gempa lagi dengan besaran 4-4,1 yang terjadi pada kurun waktu Juni - September 2015. Sedangkan 2 gempa yang terjadi paling dekat waktunya dengan gempa Sumba adalah gempa M 4,5 pada 11/2/2016 dan M 4 pada 26/1/2016 (anak panah pada Gambar 6).

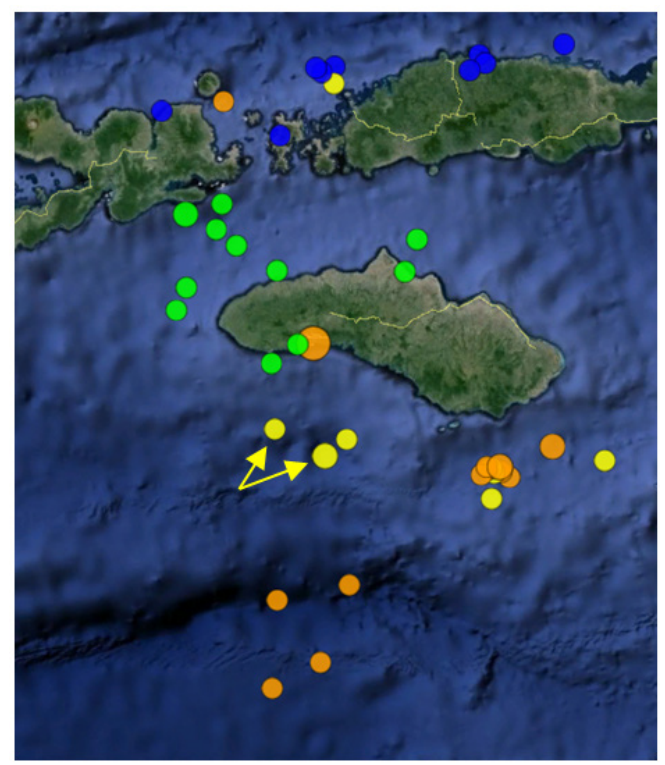

Gambar 6. Peta Sebaran Titik Gempa dari 2015$2016(4 \leq M \leq 7)$ (USGS)

Sedangkan menurut peta sebaran gempa dari Engdahl, terlihat bahwa ada beberapa titik gempa pernah terjadi di daratan Sumba, akan tetapi kedalamannya lebih dari $75 \mathrm{~km}$ (Gambar 7). Ada hal yang menarik dari peta ini, di mana pusat-pusat gempa yang terdapat di Sumba adalah gempagempa dengan kedalaman $>75 \mathrm{~km}$. 


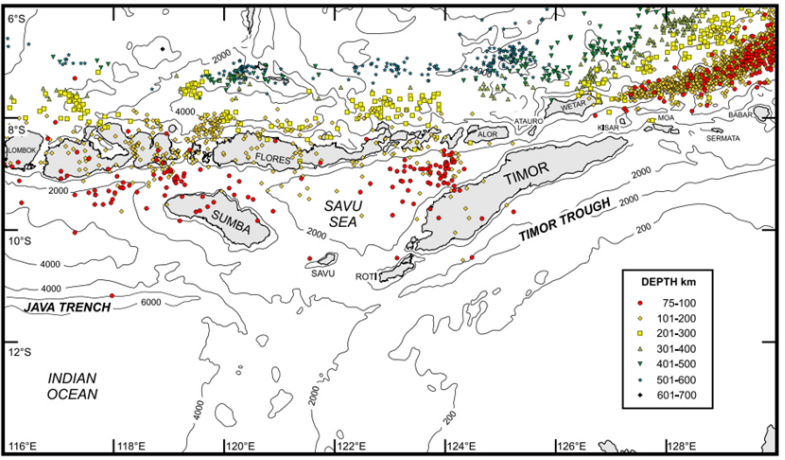

Gambar 7. Peta Sebaran Gempa di Daerah Sumba-Flores

(Engdahl et al.1998)

Ada dua sumber informasi tentang titik Gempa Sumba yang terjadi pada tanggal 12 Februari 2016, yaitu dari BMKG dan USGS. Ada perbedaan informasi dari kedua lembaga tersebut, seperti yang tertera pada Tabel 1 berikut:

Tabel 1. Perbandingan Data Gempa Sumba dari Sumber Informasi

\begin{tabular}{|l|l|l|}
\hline \multicolumn{1}{|c|}{$\begin{array}{c}\text { JENIS } \\
\text { DATA }\end{array}$} & \multicolumn{1}{c|}{ BMKG } & \multicolumn{1}{c|}{ USGS } \\
\hline Tanggal & $12-02-2016$ & $12-02-2016$ \\
\hline Jam & $17: 02: 24 \mathrm{WIB}$ & $17: 02: 23 \mathrm{WIB}$ \\
\hline Magnitudo & 6,6 & $6,3 \mathrm{Mw}$ \\
\hline Kedalaman & $\begin{array}{l}10 \mathrm{~km} \text { dikoreksi } \\
\text { jadi } 60 \mathrm{~km}\end{array}$ & $28 \mathrm{~km}$ \\
\hline Posisi & $\begin{array}{l}9.77 \mathrm{LS} ; \\
119.346 .610 \mathrm{BT}\end{array}$ & $\begin{array}{l}9,744 \mathrm{LS} ; \\
119,451 \mathrm{BT}\end{array}$ \\
\hline
\end{tabular}

Bila diukur jarak antara kedua titik sumber gempa tersebut, terdapat perbedaan jarak 12 km (Gambar 8). Selain itu, ada perbedaan yang mencolok atas penentuan kedalaman gempa, di mana dari USGS hampir separuhnya dari kedalaman BMKG. Kedalaman sangat berpengaruh pada luasan dampak gempa. Pada kasus gempa dengan kedalaman besar akan sangat berasa sampai pada luasan yang besar, sedangkan pada gempa dangkal akan sebaliknya namun berdampak nyata pada daerah di sekitar episenter dan perubahan horisontal menjauh episenter atas dampak gempa sangat besar/nyata.

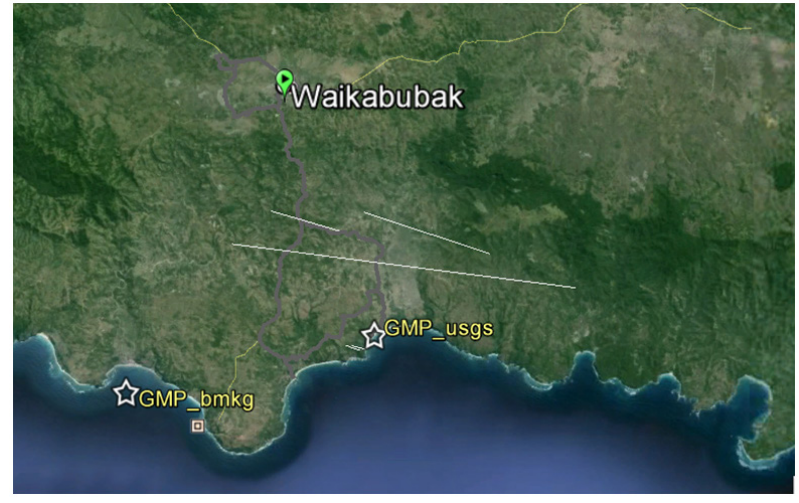

Gambar 8. Titik Episenter Gempa BMKG dan USGS

Sebagai gambaran tambahan untuk mengetahui besar dampak gempa yang pernah terjadi, khususnya gempa berepisentrum di darat seperti yang terjadi di Sumba ini, dapat dilihat pada Tabel 2 berikut:

Tabel 2. Contoh Gempa Darat dan Dampaknya

\begin{tabular}{|l|l|l|l|l|}
\hline \multicolumn{1}{|c|}{ GEMPA } & Yogyakarta & \multicolumn{1}{|c|}{ Papua } & \multicolumn{1}{c|}{ Bali } & \multicolumn{1}{c|}{ Liwa } \\
\hline Tanggal & $27 / 5 / 2006$ & $25 / 6 / 1976$ & $12 / 1 / 1917$ & $15 / 2 / 1994$ \\
\hline Magnitudo & $6,3(5,9 \mathrm{Mb})$ & 7,1 & 6,6 & $6,5 \mathrm{Mw}$ \\
\hline Dampak & 6.234 jiwa & 5.422 & 1.500 & 196 \\
\hline Sumber & Darat & Darat & Darat & Darat \\
\hline
\end{tabular}

Pada Tabel 2 di atas, menunjukkan bahwa dampak yang ditimbulkannya oleh gempa darat sangat luar biasa. Gempa Liwa dan Yogyakarta yang berkekuatan 6,5 dan 6,3 menelan korban ratusan bahkan ribuan orang. Besaran korban ini memang sangat bergantung pada banyak faktor termasuk kepadatan penduduk/ permukimannya. Ada beberapa test kuat bangunan yang dilakukan dilapangan, di antaranya adalah yang dilakukan di kantor bupati Sumba Barat di Waikabubak dan SD Masehi di Kalimbu Kuni. Dari hasil test kedua gedung tersebut menunjukkan bahwa kualitas material gedung dalam klasifikasi baik. 


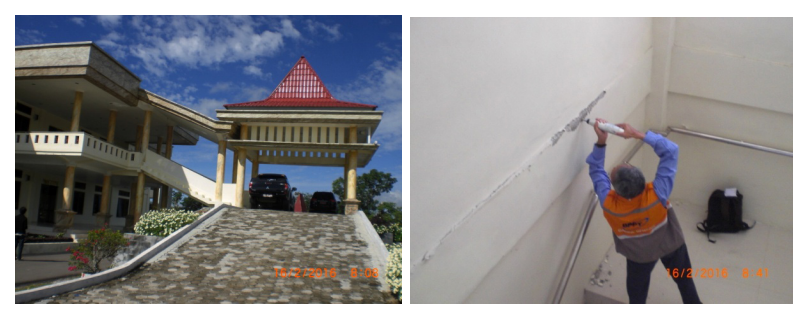

Gambar 9. Test kuat gedung di Kantor Bupati Sumba Barat
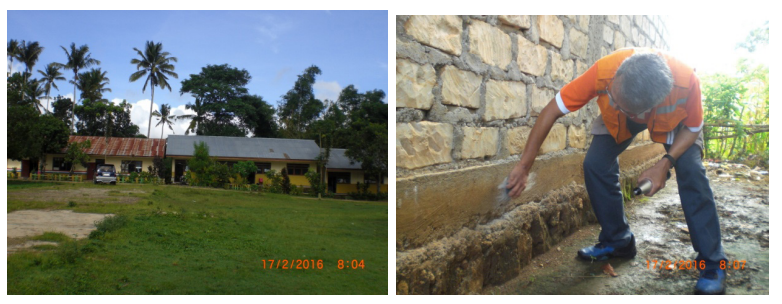

Gambar 10. Test kualitas gedung di SD Masehi, Kalimbu Kuni

Pada Gempa Sumba barat yang terjadi pada 12/2/2016 dengan besaran 6,6 (BMKG) atau 6,3 Mw (USGS) ternyata tidak banyak menimbulkan kerusakan ataupun korban jiwa. Bahkan kerusakannya sangat sedikit. Hal ini menarik perhatian, kenapa hal ini terjadi. Berdasarkan pengamatan di lapangan, terbukti bahwa sebagian besar rumah/bangunan didirikan di atas batuan tuf berselingan dengan batugamping dan dengan soil yang sangat tipis. Jadi fondasi bangunan langsung bertumpu pada batuan. Jarak Kota Waikabubak dengan pusat gempa $\pm 20 \mathrm{~km}$ dari episenter BMKG atau $15 \mathrm{~km}$ dari episenter USGS. Di luar kota Waykabubak, banyak didapatkan rumah penduduk yang masih berbentuk panggung / rumah adat (relatif fleksibel), terlebih pada daerah yang mendekati titik episenter. Dengan mempertimbangkan beberapa aspek di lapangan, penulis menyimpulkan bahwa minimnya kerusakan yang ditimbulkan oleh gempa yang cukup besar $(6,6 \mathrm{Mb})$, disebabkan oleh beberapa hal, yaitu bangunan bertumpu langsung di atas batuan, dominannya bentuk rumah panggung khususnya di sekitar episenter dan tidak ada amplifikasi gelombang gempa karena tipisnya soil (terkait dengan kondisi batuan yang terangkat cepat di Pulau Sumba, sehingga proses pelapukan masih relatif ringan), serta penulis berkecenderungan pada kedalaman gempa $60 \mathrm{~km}$ (BMKG).

Mekanisme Gempa Sumba berupa pensesaran naik. Dengan besaran gempa 6,6 Mb dengan mekanisme pensesaran naik, bila hal ini terjadi di laut, maka akan berpotensi menghasilkan tsunami. Hal ini perlu menjadikan perhatian bagi pemerintah
Sumba dan masyarakatnya, karena cukup banyak tempat-tempat wisata pantai dan permukiman yang ada di sepanjang pesisir selatan Sumba Barat.

\section{KESIMPULAN}

Batuan dasar Pulau Sumba merupakan bagian dari kerak kontinen yang sangat kompak. Perpaduan antara kompaknya batuan ini dengan tipisnya soil karena cepatnya proses pengangkatan daratan Sumba, menjadikan proses amplifikasi gelombang gempa tidak terjadi. Minimnya kerusakan yang terjadi akibat Gempa Sumba Februari 2016, selain karena tidak adanya amplifikasi, juga karena kedalaman pusat gempa yang berklasifikasi sedang yaitu $60 \mathrm{~km}$, tipisnya soil sehingga fondasi bangunan langsung di atas batuan keras, serta banyaknya rumah panggung yang relatif fleksibel dalam merespon gempa.

\section{UCAPAN TERIMAKASIH}

Pada kesempatan ini, penulis ingin mengucapkan terimakasih kepada Dr. Mulyo Harris Pradono yang telah bersama-sama melakukan pengamatan di lapangan, serta atas masukan dan diskusinya saat penulis menyusun tulisan ini.

\section{DAFTAR PUSTAKA}

Abdullah, C.I., J.P. Rampnoux, H. Bellon, R.C. Maury, R Soeria-Atmadja, 2000, The evolution of Sumba Island (Indonesia) revisited in the light of new data on the geochronology and geochemistry of the magmatic rocks, Journal of Asian Earth Sciences, Volume 18, Issue 5.

A.Spicak and J. vanek, 2016, Earthquake swarms reveal submarine magma unrest induced by distant mega-earthquakes: Andaman Sea region, Journal of Asian Earth Sciences 116.

Audley-Charles, M.G., 1981. Geometrical problems and implication of large scale overthrusting in the Banda Arc-Australian margin collision zone. In: McClay, K.R., Price, N.J. (Eds.), Thrust and Nappe Tectonics. Geological Society of London, Spec. Pub., vol. 9.

Audley-Charles, M.G., 2004, Ocean trench blocked and obliterated by Banda forearc collision with Australian proximal continental slope, Tectonophysics 389, Department of Earth Sciences, University College London, Gower Street, London WC1E 6BT, UK., SE Asia Research Group, Department of Geology, Royal Holloway, University of London, Egham, Surrey TW20 0EX, UK 
Engdahl, E.R., van der Hilst, R., Buland, R., 1998, Global teleseismic earthquake relocation and improved travel times and procedures for depth determination. Bulletin of the Seismological Society of America 88

F. Barberi, B. Bigioggero, A. Boriani ,M. Cattaneo, A. Cavallin, R. Cioni, C. Eva, R. Gelmini, E. Giorgetti, S. laccarino, F. Innocenti, G. Marinelli, D. Slejko, A. Sudradjat, 1987. The island of Sumbawa: a major structural discontinuity in the Indonesia arc. Bulletin of the Geological Society of Italy 106

L. Yanchuan, S.Xiaogang, S. Xinjian, Q. Chunyan, W.Zhenjie, 2016, Locking degree and slip rate deficit distribution on MHT fault Before 2015 Nepal Mw 7.9 Earthquake 7.9 earthquake, Journal of Asian Earth Sciences 119.

Silver, E.A., Reed, D., McCaffrey, R., Joyodiwiryo, Y., 1983. Back arc thrusting in the Eastern Sunda Arc, Indonesia: a consequence of arccontinent collision. Journal of Geophysical Research 88.

V. Babuska, B. Ružek and D Dolejs, 2016, Origin of earthquake swarms in the western Bohemian Massif: Is the mantle $\mathrm{CO} 2$ degassing, followed by the Cheb Basin subsidence, an essential driving force?, Tectonophysics. 